Article

\title{
Remuneration Committee, Board Independence and Top Executive Compensation
}

\section{Chii-Shyan Kuo ${ }^{1} *$ and Shih-Ti Yu ${ }^{2}$}

1 Faculty of Department of Accountancy, National Cheng Kung University, 1, University Road, Tainan 701, Taiwan

2 Faculty of Department of Quantitative Finance, National Tsing Hua University, 101, Sec. 2, Kuang Fu Road, Hsinchu 300, Taiwan; E-Mail: styu@mx.nthu.ed.tw

* Author to whom correspondence should be addressed; E-Mail: cooper@mail.ncku.edu.tw; Tel.: +886-6-2757575 53430; Fax: +886-6-2744104.

Received: 21 February 2014; in revised form: 10 March 2014 / Accepted: 25 March 2014 / Published: 15 April 2014

\begin{abstract}
In this study, we examine whether the levels and structures of top executive compensation vary discernibly with different levels of board independence. We also examine how the newly mandated adoption of the remuneration committee (RC) in Taiwan affects the board independence-executive pay relation. The mandatory establishment of RC for Taiwanese public firms, starting in 2011, is intended to strengthen the reasonableness and effectiveness of the executive compensation structure; thus, it is timely and of interest for practitioners and regulators to understand whether the establishment of RCs can effectively discipline top executive compensation policies. We first find that CEOs of firms that do not appoint independent directors have greater levels of annual pay than is the case for firms that have appointed independent directors, after controlling for the effect of CEO pay determinants. Second, we find that CEO pay for early RC adopters is more closely related to firm performance. Third, we find that the establishing of RCs may decrease CEO pay and enhance the pay-performance association, in particular for firms that have not appointed independent directors; however, this effect is not found to be statistically significant.
\end{abstract}

Keywords: remuneration committee; pay-performance relation; CEO compensation

JEL Classifications: J31; J33; M48 


\section{Introduction}

The purpose of this study is to examine the role of the remuneration committee (RC) in determining top management pay. Few issues have attracted as much discussion as executive compensation in the last decade. Much of the concerns centered on this issue have been mainly focused on executive pay being viewed as extravagant, unconnected with firm performance and in general not liable to sufficient scrutiny and discipline of boards of directors. Prior studies have documented evidence supporting that there is a positive relation between chief executive officer (CEO) compensation and firm market-based performance (e.g. [1,2]). However, these studies used data mainly from the U.S., where compensation committees have been functioning well. In this study, we investigate these issues by considering some empirical evidence from Taiwan.

Compared with U.S. firms, Taiwanese firms tend to have weaker corporate governance structure and higher family control and ownership concentrations (e.g. [3]). A number of companies are managed in the form of corporate conglomerates, thereby structuring a complicate web of cross-holdings, which easily leads to agency conflicts between controlling and minority shareholders. As is evident by the separation of cash flow rights from control rights, the controlling shareholders in Taiwanese firms tend to expropriate private interests by appointing family or affiliated board members on the board (e.g. [4]).

To address the public's concerns regarding the effectiveness and reasonableness of top executive pay, the legislative body of Taiwan amended the Securities and Exchange Law on 24 November 2010 to require that all listed companies establish RCs. ${ }^{1}$ Subsequently, the Financial Supervisory Committee (FSC) announced the "Regulations on the Establishment of Remuneration Committee, and the Exercise of its Authority by listed Companies" (hereafter, the Regulations) which came into effect on 18 March 2011. Under the newly promulgated Regulations, a listed company with pain-in capital above New Taiwan Dollars (NTD) \$10 billion (i.e., USD \$0.3 billion) was required to install RCs by 30 September 2011, while those with paid-in capital under NTD \$10 billion were required to complete the installation by 31 December 2011. We summarize the timeline of rules governing the setup of RCs in Figure 1.

The absence of compensation committees should be a minor issue since the boards are appointed to act on behalf of the shareholders to monitor and discipline top executive compensation. This is particularly the case if firms have previously appointed independent directors on their boards. According to the Securities and Exchange Act of Taiwan, listed companies may elect to appoint independent directors in accordance with their articles of incorporation. However, about 700 (or 50\%) of the listed firms do not adopt independent directors because this rule is not mandatorily applied to all firms. This setting provides researchers a chance to assess the differential effect of the 2011 mandatory Regulation on top management remuneration policies existing between firms with and without the

\footnotetext{
According to the Securities and Exchange Law (Article 14-6), a company whose stock is listed on the Taiwan stock exchange (TSE) or traded in the over-the-counter (OTC) market shall establish a remuneration committee. Regulations governing the professional qualifications for its members, the exercise of their powers of office, and related matters shall be prescribed by the Financial Supervisory Committee (FSC). Top executive remuneration includes cash salary, stock options, stock bonuses, retirement benefits and severance pay, various subsidies and allowances, and other material incentives.
} 
appointment of independent directors. The purpose of the establishment of an $\mathrm{RC}$ is to strengthen the reasonableness and effectiveness of executive compensation structure; thus, it is timely and of interest for practitioners and regulators to understand if the establishment of RCs can effectively discipline top executive compensation policies.

Figure 1. Timeline of regulations for the remuneration committee (RC).

On 24 November 2010, the legislative body of Taiwan has amended the Securities and Exchange Law (Article 14-6) to require that all listed companies should establish RCs.
According to the newly promulgated Regulation, a listed company with paid-in capital equal to or greater than NTD \$10 billion (USD $\$ 0.3$ billion) shall establish a $\mathrm{RC}$ by 30 September 2011 and shall convene at least one meeting by 31 December 2011 . According to the FSC, there are 116 companies meet the criteria and they all have established RCs by the deadline.

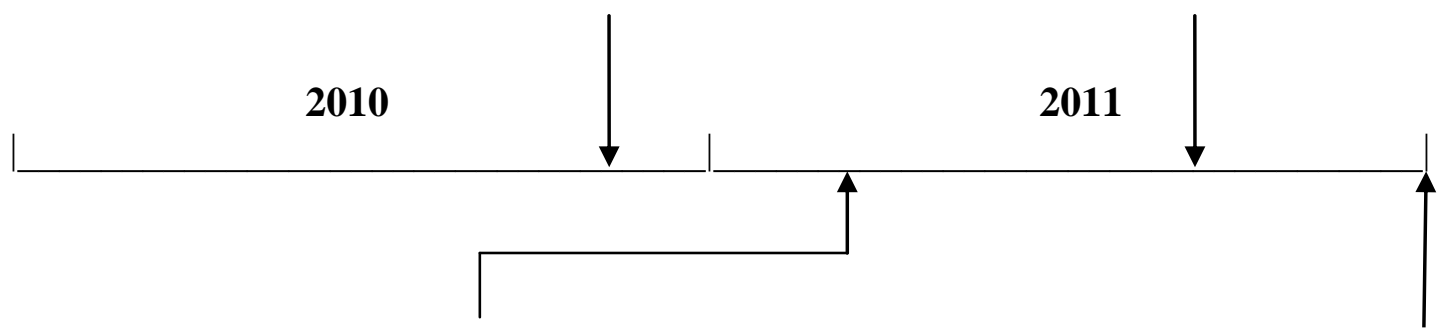

"Regulations on the Establishment of Remuneration Committee, and the Exercise of its Authority by Listed Companies" (the Regulations) came into effect on 18 March 2011.
Based on the Regulation, a listed company with paid-in capital of less than NT \$10 billion may establish RC by 31 December 2011 and shall be exempted from the provision concerning the number of meeting convened. The FSC stated that there are 1,528 companies meet the criteria and there are only few companies have done so until 15 October 2011.

\footnotetext{
Note: PwC Taiwan pointed out that out of 1,300 listed firms in Taiwan, only 22 (less than 2\%) have established RC or special committee with equivalent functions

(Source: $\mathrm{http} / / \mathrm{www}$. pwc.com/tw/en/news/press-release/press-20110322.jhtml).
}

We find CEOs of firms that have not appointed independent directors have greater levels of annual pay than is the case for firms that have done so, after controlling for the effect of CEO pay determinant variables. Second, we find CEO pay for RC early adopters to be more tightly associated with firm performance. Third, we find that the establishment of RCs may lower CEO pay and enhance the payperformance relation, in particular, for firms that have not appointed independent directors; however, this effect is insignificant.

The possible contributions of this study are twofold. First, this study contributes to the top executive compensation literature by providing evidence from a jurisdiction which differs remarkably from those of the US and Europe. In particular, the firm corporate governance structure and the level of governmental regulation in Taiwan could be very different from those in the US and European jurisdictions. We believe that the growing development of CEO compensation literature can benefit from further evidence on the effects of corporate governance reforms obtained from diverse economic environments. One 
purpose of this study is to add to this stream of literature by improve the understanding of the function of RC in an international setting. In view of the importance of Taiwan in the Asia-pacific regions and the rapidly growing globalization, such an understanding is crucial to academics, regulators and practitioners in the world. Second, this study covers a period during which the authorities with responsibility for board independence reforms adopt an approach of gradual enforcement. This unique and natural setting allows Taiwanese companies to use considerable discretion as to whether they choose to voluntarily appoint independent directors on their boards. Thus, researchers can assess the effectiveness of this regulatory reform by comparing the incremental monitoring function driven by the installment of RCs beyond that of the independent directors with that derived solely from the establishment of RCs in firms that have not appointed independent directors.

The remainder of this paper is organized as follows: Section 2 discusses board independence policy reforms in Taiwan with a particular focus on the regulatory changes, relevant theories in the existing literature and hypotheses formulation. Section 3 presents the methodology. Section 4 describes the data. Section 5 documents and discusses the empirical findings. Section 6 concludes this paper.

\section{Prior Studies and Hypothesis Development}

Designed to strengthen board independence, the 2002 amended Securities and Exchange Act of Taiwan requires a firm first filing for listing to appoint independent directors. Subsequently, the 2006 amended Securities Exchange Act (Article 14-2) further stipulates that financial institutions and listed firms with paid-in capital of NTD \$50 billion (USD \$1.6 billion), as well as newly listed firms, are required to appoint independent directors. However, since this board reform is not mandatorily applied to all firms, about 700 (or 50\%) of the listed firms actually do not appoint independent directors. ${ }^{2}$

The board of directors is deemed a crucial corporate governance mechanism [6]. One primary function of the board is to determine the structure and level of top management pay (e.g. [7,8]). Ideally, the "Boards should appoint remuneration committees, consisting wholly or mainly of non-executive directors and chaired by a non-executive director, to recommend to the board the remuneration of executive directors in all its forms, drawing on outside advice as necessary. Executive directors should play no part in decisions on their own remuneration" [9]. ${ }^{3}$

Independent or non-executive directors have incentives to signal their managerial competence to other potential employers. Further, they often already have expertise related to monitoring a top management team and thus are experts in internal organizational control (e.g., [6,11]). Therefore, the level of board independence plays a major role in the effectiveness of executive compensation in regard to reducing the agency problem (e.g. [11,13-17]) and positively relates to constraints on managerial influence [18].

For example, [5].

Relatedly, the Greenbury Committee [10] urged the adoption of RCs consisting of solely nonexecutive directors. Similarly, the U.S. Securities and Exchange Committee (SEC) in 1992 adopted provisions encouraging nonexecutive directors to be more responsible for establishing executive pay by increasing disclosure requirements when corporate insiders serve on RCs. In addition, the 1993 congressional tax code stipulates that RCs must be composed solely of two or more nonexecutive directors, or performance-based executive pay in excess of USD \$1 million is not tax deductible. The listing requirements of the New York Stock Exchange (NYSE) and NASDAQ mandate majority-independent boards. The NYSE also requires entirely independent compensation committees. The NASDAQ rules are similar, while more flexible, than the NYSE (e.g., [11,12]). 
On the other hand, others have argued that outside directors could be ineffective in monitoring top management because they, in general, hold only a small fraction of ownership and financial stakes, which could dampen their monitoring capacity (e.g. [14,19]). Further, the independence of non-executives could be weakened if they are appointed by a CEO or previous members of the firm management team [14,20]. ${ }^{4}$ Moreover, [21] argued that insiders may provide a beneficial monitoring function since they may better understand the social and political aspects of a firm that are useful for compensation advisors in regard to structuring incentives. Congruent with their argument, [21] found that an increase in board independence has little impact on pay levels.

Taken together, prior studies offer no uniform evidence as to whether greater levels of board independence contribute to more efficient managerial pay contracts. However, if overly high top executive pay is related to agency problems driven by the separation of ownership from control, we expect to observe that firms with an executive-dominated board will tend to have higher levels of top managerial pay. Based on the above arguments, we formulate the first hypothesis in the alternative form as follows: ${ }^{5}$

\section{H1: Top executive compensation levels will be relatively higher in firms that choose not to voluntarily adopt independent directors.}

In Taiwan, even after posting consecutive losses, some companies with insider-dominated boards continue to award their top executives huge compensation packages. Thus, the main purpose of the mandatory adoption of RCs is to preclude inefficient design of managerial pay contracts of this kind [22]. The intent behind the policy reform is to prevent top executives playing any role in the determination of their own compensation, which may not be commensurate with shareholder interests. Accordingly, the installation of RCs potentially may have an important positive impact on the exercise of board control [14].

However, some prior studies have provided an alternative view as to the effectiveness of RCs. For example, [23] found that the average pay for RC members positively affects the level of CEO pay. They interpreted these results as being consistent with the social comparison theory perspective. Furthermore, [24] found that relatively underpaid executives may enjoy a pay raise; however, no equivalent downward modification occurs in the case of overly paid executives. Based on their findings, they proposed a "bidding up" hypothesis. Namely, it was suggested that both executive and non-executive directors sit on each other's RCs and thereby bid up executive pay. Similarly, [25] found that executive pay is significantly higher in firms adopting RCs.

In Taiwan, concerns expressed by the popular press related to excessive CEO pay have greatly caused popular awareness of the "fat cat" issue. This led to the recent regulatory and policy reforms.

4 However, this position does not necessarily imply an association between affiliated or interdependent RC members and CEO compensation $[11,15]$. One possible reason for this is that affiliated or interdependent directors serving on a powerful committee are mindful of their duty to shareholders, regardless of their level of dependence [11].

5 In contrast to the alternative form, the null hypothesis states that voluntary appointment of independent directors has no impact on the levels of CEO pay. Though prior studies have provided conflicting evidence regarding how the independence of boards affects the CEO pay levels, to the extent that the board independence can reasonably reduce the agency cost we expect to observe a higher level of CEO pay for non-adopters of independent directors. To formulate hypotheses in an alternative form can be widely seen in prior accounting or finance research papers. In this study we also follow this convention. 
Such strengthened scrutiny of executive directors, coupled with scrutiny of CEO compensation, could lessen any director intent to award excessive compensation. Accordingly, this leads us to expect the executive compensation for firms previously failing to adopt independent directors on their boards to become lower after the mandatory requirement of RCs. Thus, we formulate the second hypothesis in the alternative form as follows:

H2: Compared to that of firms with voluntarily appointed independent directors, the top executive compensation for firms currently without appointment of independent directors is expected to become lower to a greater extent after the mandatory enforcement of RCs.

Prior studies have suggested that regulatory intervention by governance may effectively change compensation behavior. For example, [17,22] found firms to have reduced salaries in response to compensation disclosure and tax reform and pay-performance sensitivity to accordingly be increased for the firms most likely to be affected. ${ }^{6}$ In addition, using a separation of tasks and functions framework, [27] found pay-performance sensitivity to be higher when the RC sets the CEO pay, and the audit committee monitors the financial reporting, rather than when the board as a whole handles both. Relatedly, [28] found future firm performance to be more positively associated with stock option grants as RC quality increases. Furthermore, [29] argued that outside directorships are considered to be valuable since they provide executives with prestige, visibility, and commercial contacts. This line of argument suggests that companies, with an objective to increase their value, will have a demand for independent directors to serve on their boards [30]. This positive value effect may be attributable to their expert advisory, actual monitoring and probably a favorable signaling effect. This reputation view can be found to be supported in a number of studies. For example, [31] found the number of outside directorships to be associated with firm performance in the case of financially distressed firms. [32] found the number of independent directors to be related to dividend cuts.

On the contrary, [21] contended that the above-mentioned regulations do enhance RC independence but found no evidence to support the premise that the presence of insiders on RC weakens payperformance sensitivity.

In Taiwan, the government policy reform mandates the establishment of RCs, composed of only independent directors and thereby is expected to serve as a supplementary measure and positive force to strengthen the pay-performance relation for such firms. Therefore, we formulate the third hypothesis in alternative form as follows:

\section{H3: The pay-for-performance relation strengthens after the mandatory enforcement of RCs.}

The effect of outside directors and board monitoring functions is not only on the level of pay. A crucial role of a non-executive director-dominated board is to design an effective pay contract so that top managers have an incentive to work in line with shareholder interests (e.g., [14,15]). Consistent with this view, [16] found a positive relation between the percentage of independent outside

6 Moreover, [26] suggested that the increasing use of non-executive directors has a positive impact on U.K. board structure and governance arrangements. 
directors and CEO pay-performance sensitivity. Moreover, [33] found independent directors to have a bargaining advantage over CEOs that results in compensation more closely aligned with shareholder objectives.

Conversely, an alternative view contends that insiders could be more motivated to exert managerial control since their reputation as decision-makers largely depends on the quality of their compensation policy. Additionally, insiders could own an informational advantage over nonexecutives in assessing both firm strategy and the economic environment. As such, insiders could be in a better position to establish more efficient pay arrangements [17]. Consistent with this view, [21] found RC independence to have no significant effect on the pay-performance association and therefore concluded that the regulations impose regulatory and firm specific costs without offsetting benefits.

Given the mixed results provided by the prior literature on this topic, whether RC installation for firms previously without the appointment of independent directors can positively affect the pay-for-performance relation appears to be an empirical question. We therefore list the fourth hypothesis in the alternative form as follows:

H4: The pay-performance relation becomes closer to a greater extent after the mandatory adoption of RCs for firms appointing no independent directors.

If the lack of mandatory $\mathrm{RC}$ requirement hampers effective monitoring of executive compensation, companies with the least efficient compensation packages could be most resistant to the introduction of RCs because these firms are the ones that will experience the most adverse reaction from the financial media and shareholders when their undue remuneration policies are made public. As such, we expect such companies to have the strongest motives to delay the setting up of RCs until the last possible moment. By contrast, companies that choose to install RCs early appear a priori to be least affected by the new rule. Therefore, we formulate the third hypothesis in alternative form as follows:

H5: Companies that voluntarily install RCs early will exhibit a closer pay-performance relation than will be the case for firms that delay the establishment of RCs until they are absolutely required to do so.

\section{Methodology}

To address our research questions, we express the level of CEO compensation as a function of firmspecific corporate governance structures, economic factors and ownership structures (e.g., [34, 38] ), listed as follows: ${ }^{7}$

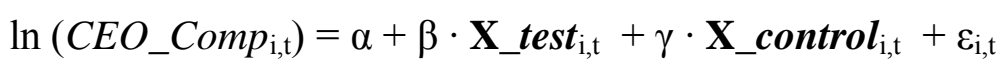

Annual CEO pay (CEO_Comp) includes cash compensation, other special allowances, cash bonuses, and stock bonuses. According to the rule, each firm discloses only the upper and lower bounds of

\footnotetext{
To test our hypotheses, we need to control for the effects of CEO pay determinants which can affect the CEO pay level but are irrelevant to our research questions. Therefore, in our model specification, we include economic determinants of top executive pay, including firm growth potential, operating risk, firm size and firm performance [34-36].
} 
annual CEO compensation, and therefore the actual dollar amount of CEO pay for each firm is unavailable. For regression analysis purposes, we use the midpoint of the disclosed CEO annual salary range for each firm. We then transform compensation data into its logarithm. ${ }^{8} \mathbf{X} \_$control represents the control variables used, i.e., the economic determinants of CEO compensation, including firm performance, firm size, growth potential, and risk variables (e.g. [37,38]).

To measure firm performance, we use annual stock return (Ret) and return on asset (Roa). Further, firm size (Firm_Size) is measured by the natural logarithm of net sales [34]. Next, Market-to-Book is the market value of equity divided by the book value of equity, serving as a proxy for growth opportunity (e.g. [38,39]). Further, we use both standard deviations of stock returns (Stdev_Ret) and standard deviations of return on assets (Stdev_Roa) for the past five years to capture firm risk.

Moreover, we include in the regression two corporate governance variables, CEO duality (CEO_Chair) and board size (Board_Size) to control for the effect of corporate governance structure on executive pay. CEO_Chair is a dummy, equal to one if the CEO is the chair of the board. Board_Size is the number of directors sitting on the board. Further, we add three ownership structure variables to our regression, including CEO ownership (CEO_Ownership), inside director ownership (Dir_Ownership) and ownership concentration (Large_Ownership). CEO_Ownership is the number of shares held by a CEO divided by the total number of shares outstanding. Dir_Ownership is the number of shares owned by insider directors divided by the total number of shares outstanding. Lareg_Ownership is the number of shares held by shareholders whose holdings are more than 5\% of the firm's shares divided by the number of shares outstanding. Lastly, we add Year-dummies and Industry-dummies to the regression to control for industry and year effects and $i$ and $t$ denote CEOs and years, respectively. ${ }^{9}$

$\mathbf{X} \_$test represents for the variables we use to test our hypotheses. To test H1, we define $\mathbf{X} \_t$ test as a dummy variable, Non_IndDir, which equals one if firms have not voluntarily appointed independent directors on the board, and zero otherwise. An observed significant positive coefficient on Non_IndDir will support $\mathrm{H} 1$.

To test H2, we define $\mathbf{X}$ test as three sets of variables, including Non_IndDir, RC_Setup and Non_IndDir $\times$ RC_Setup. RC_Setup equals one if year is 2011, and zero otherwise. An observed significant negative coefficient on Non_IndDir $\times$ RC_Setup is consistent with H2.

To test whether pay-performance relation enhances after the mandatory enforcement of RCs (H3), we define X_test as RC_Setup and Ret $\times$ RC_Setup. An observed positive coefficient on Ret $\times$ RC_Setup will support H3.

For testing H4, X_test are defined as Non_IndDir, RC_Setup and Ret $\times$ RC_Setup $\times$ Non_IndDir. An significantly positive coefficient on Ret $\times$ RC_Setup $\times$ Non_IndDir will support H4.

8 One major reason for the use of log-transformed CEO compensation in our regression analysis is that the "guide charts" are constructed by regressing the logarithm of pay on the logarithm of firm size (e.g., [40]). This practice is widely used by human resource consultants to determine the pay levels [34].

9 We do not use a lag structure in our model specification because our interest is mainly on the contemporaneous payperformance association and the levels of CEO pay are determined largely on the firm performance rather than on the pay level for the previous period. In addition, the year-dummies and industry-dummies are chosen based on the sample period (i.e., 2008-2011) and 27 industry sectors, based on the TSE industry classification codes. 
Lastly, to test $\mathrm{H} 5$, we define $\mathbf{X} \_$test as $R C_{-}$EarlyAdopter and an interaction term Ret $\times$ RC_EarlyAdopter.

An observed significant positive coefficient on Ret $\times$ RC_EarlyAdopter is consistent with H5.

\section{Data}

The sample includes firms listed in the Taiwan Stock Exchange (TSE), Over-the-Counter (OTC) and Emerging Stock (ES) markets at the 2011 fiscal year-end. We collect financial and stock return data for the 2008-2011 period, covering three years prior to and one year after the mandatory enforcement of RC installation. The initial data consists of 1,734 firms, representing 6,936 observations. We exclude from our dataset 48 firms or 192 firm-year observations within the financial industry, e.g., banking, insurance companies and regulated industries. We collect CEO compensation data from sample firm annual reports. We delete 811 firm-year observations due to missing CEO annual pay data. In addition, we delete 1,106 observations because the firm historical annual stock returns needed to calculate standard deviations or annual stock returns for the current year are missing. Further, 37 observations are deleted because of missing net sales. We also delete 43 observations due to missing CEO ownership data. The final data set used to test our hypotheses includes 4,747 firm-year observations, representing 1,311 distinct firms. ${ }^{10}$ Table 1 summarizes the sample selection procedure.

Table 2 summarizes the descriptive statistics of all variables used in the study. The average dollar amount of the upper (lower) bound of annual CEO pay (CEO_Comp) is NT\$ 6.97 (NT\$ 3.08) million. Further, the mean of the midpoint CEO compensation is NT\$ 5.03 million and the first (third) quartiles of the average CEO_Comp are NT\$ 1.42 (NT\$ 7.50) million. ${ }^{11}$

As shown in Table 2, the mean of annual stock return (Ret) and return on assets (Roa) are $23.98 \%$ and $3.43 \%$, respectively. Standard deviations of these two variables suggest that Ret demonstrates greater deviation then Roa over the sample period, which is more than ten times that of Roa. Next, the average natural logarithm of net sales (Firm_Size) is 14.66, representing an average net sales of NT\$ 12.5 million. The mean (median) of market value to book value of equity (Market-to-Book) is 1.58 (1.22), indicating that sample firms on average demonstrate growth potential. In addition, the standard deviations of Ret and Roa for the past five years are $74.89 \%$ and $5.87 \%$, respectively.

Furthermore, the mean of CEO_Chair is 0.31, suggesting that nearly one-third of CEOs also serve as Chairman of the Board. Next, the average number of directors sitting on the board is 6.83 , and the median is 7 . In addition, the average holdings of CEOs are $3.21 \%$. The mean of director ownership (Dir_Ownership) and large shareholder ownership (Large_Ownership) are 20.53\% and 19.81\%, respectively. Finally, the mean of Non_IndDir is 0.51 , meaning that on average half of the sample do not have independent directors sitting on their boards.

10 If sample firms do not meet the listing requirements of TSE for some reasons (e.g., financial distress), they are required to stop trading temporarily or delisted by the authority. This is the main reason why the stock price, financial and CEO pay data are missing.

11 Untabulated statistics show that the average CEO annual compensation increases over the 2008-2010 period. The means of the midpoint of CEO annual pay are NT\$ 4.64 (NT\$ 4.71 and NT\$ 5.41) million for 2008 (2009 and 2010). However, the mean drops a little in 2011, which is NT\$ 5.28 million. 
Table 1. Sample selection criteria.

\begin{tabular}{|c|c|c|}
\hline & & $\begin{array}{c}\text { Num of } \\
\text { firm-year } \\
\text { observations }\end{array}$ \\
\hline $\begin{array}{c}1,734 \\
\text { and } \mathrm{E}\end{array}$ & $\begin{array}{l}\text { ms listed in the Taiwan Stock Exchange (TSE), Over-the Counter (OTC), } \\
\text { erging Stock (ES) markets at the } 2011 \text { fiscal year-end from } 2008 \text { to } 2011\end{array}$ & 6,936 \\
\hline \multirow[t]{6}{*}{ Less: } & Firms within the financial industry & $(192)$ \\
\hline & CEO compensation data are missing & $(811)$ \\
\hline & $\begin{array}{c}\text { Historical annual stock return }(\text { Ret }) \text { to calculate standard deviation of Ret } \\
\text { or Ret for current year are missing }\end{array}$ & $(1,106)$ \\
\hline & Net sales to measure firm size (Firm_Size) are missing & $(37)$ \\
\hline & CEO ownership (CEO_Ownership) data are missing & $(43)$ \\
\hline & $\begin{array}{l}\text { Final sample } \\
\end{array}$ & 4,747 \\
\hline
\end{tabular}

Table 2. Sample selection criteria.

\begin{tabular}{ccccccc}
\hline Variable & Unit & Mean & Std.dev. & Q1 & Median & Q3 \\
\hline CEO_Comp (upper) & NT\$ & $6,970,603$ & $8,706,381$ & $2,832,000$ & $5,000,000$ & $10,000,000$ \\
CEO_Comp (lower) & NT\$ & $3,084,053$ & $4,842,515$ & 0 & $2,000,000$ & $5,000,000$ \\
CEO_Comp (average) & NT\$ & $5,027,328$ & $6,744,760$ & $1,416,000$ & $3,500,000$ & $7,500,000$ \\
Ret & $\%$ & 23.98 & 107.18 & -41.23 & -11.73 & 49.16 \\
Roa & $\%$ & 3.43 & 10.54 & 0.36 & 4.28 & 8.69 \\
Firm_Size & & 14.66 & 1.56 & 13.69 & 14.56 & 15.56 \\
Market-to-Book & & 1.58 & 2.47 & 0.80 & 1.22 & 1.85 \\
Stdev_Ret & $\%$ & 74.89 & 64.52 & 37.39 & 59.28 & 92.06 \\
Stdev_Roa & $\%$ & 5.87 & 5.31 & 2.58 & 4.42 & 7.28 \\
CEO_Chair & & 0.31 & 0.46 & 0 & 0 & 1 \\
Board_Size & & 6.83 & 2.11 & 5 & 7 & 7 \\
CEO_Ownership & $\%$ & 3.21 & 4.75 & 0.10 & 1.30 & 4.59 \\
Dir_Ownership & $\%$ & 20.53 & 13.50 & 10.86 & 16.67 & 26.36 \\
Large_Ownership & $\%$ & 19.81 & 11.38 & 11.77 & 17.91 & 25.53 \\
Non_IndDir & & 0.51 & 0.50 & 0 & 1 & 1 \\
\hline
\end{tabular}

\section{Empirical Findings}

To test the first hypothesis, we run regression analysis and document the results in column (1) of Table 3. The coefficient on Non_IndDir is $0.07(\mathrm{t}=2.53)$, which is significant at the $5 \%$ significance level. $^{12}$ This result suggests that CEO annual compensation is relatively higher for firms that

12 For the regression analysis of the first hypothesis, we conduct two sets of diagnostic tests. First, we run Breusch-Pagan test for heteroskedasticity. The chi-square is 8.54 , which rejects the null of constant variance at the $1 \%$ significance level. Second, we run the test for autocorrelation in the panel data; the F-statistics is 75.42 , which reject the null of no first-order autocorrelation at the $1 \%$ significance level. To address these issues, we calculate the t-statistics (in parentheses) based on [41] heteroskedasticity and autocorrelation-consistent standard errors. Since the diagnostic checks for regression analyses from the second to the fifth hypotheses all reject the null of homogeneity of variance and 
voluntarily choose not to appoint independent directors, consistent with H1. It should be noticed that the coefficient estimates on risk variables (i.e., Stdev_Ret and Stdev_Roa) are negative; however, they are insignificant. Other control variables, including firm performance, firm size, growth potential, corporate governance and ownership variables have the expected signs and are consistent with prior studies.

Column (2) documents the test results for H2. We find the coefficient on Non_IndDir $\times$ RC_Setup to be negative $(-0.01, \mathrm{t}=-0.25)$, which is consistent with $\mathrm{H} 2$, but it is insignificant.

The test results for $\mathrm{H} 3$ are shown in column (3) of Table 3. The coefficient estimate (t-statistics) on Ret $\times R C$ _Setup is $0.001(\mathrm{t}=0.88)$. The result indicates that the association between CEO pay and stock return (i.e., pay-performance sensitivity) enhances after the setup of remuneration committees, but the impact is insignificant.

To test whether the pay-performance relation becomes closer to a greater extent after the mandatory adoption of RCs for firms appointing no independent directors (H4), we run equation and report the results in column (4) of Table 3. The coefficient on Non_IndDir $\times$ Ret $\times$ RC_Setup is $0.001(\mathrm{t}=0.57)$, which shows an expected but insignificant positive sign. This finding suggests that RCs have a positive impact on the pay-performance association for firms without independent directors sitting on their boards; however, the impact is insignificant.

Lastly, we document the test results for H5 in column (5). The coefficient estimate on Ret $\times$ $R C \_$EarlyAdopter is $0.003(\mathrm{t}=2.38)$, which is significant at the $5 \%$ level. This finding indicates that the pay-performance association for companies that voluntarily install RCs early becomes closer to a greater degree than firms that delay the establishment of RCs until they are absolutely required to do so, which is consistent with $\mathrm{H} 5 .^{13}$

no autocorrelation, in Table 3 we report t-statistics based on [41] heteroskedasticity and autocorrelation-consistent standard errors for all test results.

13 We notice that the adjusted R-squares reported in Table 3 seem comparable. Even though some of the above coefficient estimates are significant, Non_IndDir, RC_Setup, Non_IndDir $\times$ RC_Setup, Ret $\times$ RC_Setup, Non_IndDir $\times$ Ret $\times$ $R C \_S e t u p, R C \_E a r l y A d o p t e r$ and Ret $\times R C \_E a r l y A d o p t e r$ have negligible explanatory power for $\ln (\mathrm{CEO}$ _Comp), causing adjusted R-squares to remain barely unchanged. 
Table 3. Summary of test results from regressions of natural logarithm of annual CEO compensation on firm performance, firm size, growth potential, firm risk, corporate governance and ownership structure variables.

\begin{tabular}{|c|c|c|c|c|c|c|}
\hline \multirow[b]{2}{*}{ Independent Variables } & \multirow[b]{2}{*}{$\begin{array}{l}\text { Pred. } \\
\text { sign }\end{array}$} & \multicolumn{5}{|c|}{ Dependent Variable: $\operatorname{Ln}\left(C E O \_C o m p\right)$} \\
\hline & & (1) & $(2)$ & (3) & (4) & $(5)$ \\
\hline Intercept & $?$ & $\begin{array}{l}11.03 * * * \\
(60.06)\end{array}$ & $\begin{array}{l}11.22 * * * \\
(60.11)\end{array}$ & $\begin{array}{l}11.24 * * * \\
(59.98)\end{array}$ & $\begin{array}{l}11.22 * * * \\
(60.29)\end{array}$ & $\begin{array}{l}11.25^{* * *} \\
(59.95)\end{array}$ \\
\hline Ret & + & $\begin{array}{l}-0.0001 \\
(-0.87)\end{array}$ & $\begin{array}{c}-0.0001 \\
(-0.83)\end{array}$ & $\begin{array}{c}-0.0002 \\
(-1.03)\end{array}$ & $\begin{array}{c}-0.0001 \\
(-0.94)\end{array}$ & $\begin{array}{c}-0.0001 \\
(-0.97)\end{array}$ \\
\hline Roa & + & $\begin{array}{l}0.02 * * * \\
(10.57)\end{array}$ & $\begin{array}{l}0.02 * * * \\
(10.59)\end{array}$ & $\begin{array}{l}0.02 * * * \\
(10.43)\end{array}$ & $\begin{array}{l}0.02 * * * \\
(10.59)\end{array}$ & $\begin{array}{l}0.02 * * * \\
(10.26)\end{array}$ \\
\hline Firm_Size & + & $\begin{array}{l}0.25 * * * \\
(19.95)\end{array}$ & $\begin{array}{l}0.25 * * * \\
(19.90)\end{array}$ & $\begin{array}{l}0.25 * * * \\
(20.11)\end{array}$ & $\begin{array}{l}0.25 * * * \\
(19.91)\end{array}$ & $\begin{array}{l}0.25 * * * \\
(20.10)\end{array}$ \\
\hline Market-to-Book & + & $\begin{array}{l}0.02 * * \\
(2.07)\end{array}$ & $\begin{array}{l}0.02 * * \\
(2.07)\end{array}$ & $\begin{array}{l}0.02 * * \\
(2.04)\end{array}$ & $\begin{array}{l}0.02 * * \\
(2.06)\end{array}$ & $\begin{array}{l}0.02^{* *} \\
(2.05)\end{array}$ \\
\hline$S t d e v \_R e t^{\dagger}$ & + & $\begin{array}{l}-2.55 \\
(-0.13)\end{array}$ & $\begin{array}{l}-1.94 \\
(-0.10)\end{array}$ & $\begin{array}{l}-3.42 \\
(-0.18)\end{array}$ & $\begin{array}{l}-1.54 \\
(-0.08)\end{array}$ & $\begin{array}{l}-2.17 \\
(-0.11)\end{array}$ \\
\hline Stdev_Roa & + & $\begin{array}{l}-0.001 \\
(-0.45)\end{array}$ & $\begin{array}{l}-0.001 \\
(-0.44)\end{array}$ & $\begin{array}{l}-0.001 \\
(-0.54)\end{array}$ & $\begin{array}{l}-0.001 \\
(-0.42)\end{array}$ & $\begin{array}{l}-0.002 \\
(-0.64)\end{array}$ \\
\hline CEO_Chair & + & $\begin{array}{c}0.03 \\
(0.91)\end{array}$ & $\begin{array}{c}0.03 \\
(0.92)\end{array}$ & $\begin{array}{l}0.03 \\
(1.04)\end{array}$ & $\begin{array}{l}0.03 \\
(0.93)\end{array}$ & $\begin{array}{l}0.03 \\
(0.99)\end{array}$ \\
\hline Board_Size & + & $\begin{array}{l}0.02 * * * \\
(3.31)\end{array}$ & $\begin{array}{l}0.02 * * * \\
(3.29)\end{array}$ & $\begin{array}{l}0.02 * * * \\
(2.88)\end{array}$ & $\begin{array}{l}0.02 * * * \\
(3.28)\end{array}$ & $\begin{array}{l}0.02 * * * \\
(2.66)\end{array}$ \\
\hline CEO_Ownership & - & $\begin{array}{c}-0.01 * \\
(-1.93)\end{array}$ & $\begin{array}{l}-0.01 * * \\
(-1.97)\end{array}$ & $\begin{array}{l}-0.01 * * \\
(-2.19)\end{array}$ & $\begin{array}{l}-0.01 * * \\
(-1.97)\end{array}$ & $\begin{array}{l}-0.01 * * \\
(-2.14)\end{array}$ \\
\hline
\end{tabular}


Table 3 (cont.).

\begin{tabular}{|c|c|c|c|c|c|c|}
\hline \multirow[b]{2}{*}{ Independent variables } & \multirow[b]{2}{*}{$\begin{array}{l}\text { Pred. } \\
\text { sign }\end{array}$} & \multicolumn{5}{|c|}{ Dependent Variable: $\operatorname{Ln}(\mathrm{CEO} O$ Comp $)$} \\
\hline & & (1) & $(2)$ & (3) & (4) & $(5)$ \\
\hline Dir_Ownership & - & $\begin{array}{l}-0.01 * * * \\
(-5.22)\end{array}$ & $\begin{array}{l}-0.01 * * * \\
(-5.20)\end{array}$ & $\begin{array}{l}-0.01 * * * \\
(-5.24)\end{array}$ & $\begin{array}{l}-0.01 * * * \\
(-5.22)\end{array}$ & $\begin{array}{l}-0.01 * * * \\
(-5.22)\end{array}$ \\
\hline Large_Ownership & - & $\begin{array}{l}-0.004 * * * \\
(-3.69)\end{array}$ & $\begin{array}{l}-0.004 * * * \\
(-3.66)\end{array}$ & $\begin{array}{l}-0.005 * * * \\
(-3.79)\end{array}$ & $\begin{array}{l}-0.005^{* * * *} \\
(-3.69)\end{array}$ & $\begin{array}{l}-0.004 * * * \\
(-3.87)\end{array}$ \\
\hline Non_IndDir & + & $\begin{array}{l}0.07 * * \\
(2.53)\end{array}$ & $\begin{array}{l}0.08 * * \\
(2.40)\end{array}$ & & $\begin{array}{l}0.08 * * * \\
(2.59)\end{array}$ & \\
\hline$R C \_S e t u p$ & $?$ & & $\begin{array}{l}0.23^{* * *} \\
(3.20)\end{array}$ & $\begin{array}{l}0.24 * * * \\
(3.18)\end{array}$ & $\begin{array}{l}0.23 * * * \\
(3.17)\end{array}$ & \\
\hline Non_IndDir $\times$ RC_Setup & - & & $\begin{array}{l}-0.01 \\
(-0.25)\end{array}$ & & & \\
\hline Ret $\times$ RC_Setup & + & & & $\begin{array}{l}0.001 \\
(0.88)\end{array}$ & & \\
\hline $\begin{array}{l}\text { Non_IndDir } \times \text { Ret } \times \\
\text { RC_Setup }\end{array}$ & + & & & & $\begin{array}{l}0.001 \\
(0.57)\end{array}$ & \\
\hline RC_EarlyAdopter & $?$ & & & & & $\begin{array}{l}0.17 * * \\
(2.53)\end{array}$ \\
\hline Ret $\times R C \_$EarlyAdopter & + & & & & & $\begin{array}{l}0.003 * * \\
(2.38)\end{array}$ \\
\hline Year dummies & & Controlled & Controlled & Controlled & Controlled & Controlled \\
\hline Industry dummies & & Controlled & Controlled & Controlled & Controlled & Controlled \\
\hline
\end{tabular}


Table 3 (cont.).

\begin{tabular}{llllll}
\hline $\mathrm{N}$ & 4,747 & 4,747 & 4,747 & 4,747 & 4,747 \\
Adjusted R-squared & 0.3406 & 0.3419 & 0.3409 & 0.3420 & 0.3408 \\
\hline
\end{tabular}

\section{Notes:}

$\dagger$ Coefficients on Stdev_Ret are multiplied by $10^{5}$.

$* * *, * *, *$ stand for statistically significant at the 1\%,5\%, and 10\% significance levels, respectively (two-tailed test). The $t$-statistics (in parentheses) are based on [41] heteroskedasticity and autocorrelation-consistent standard errors for panel datasets. CEO Comp is the midpoint of upper and lower bounds of CEO Comp. Ret is annual stock return. Roa is return on assets. Firm_Size is measured by the natural logarithm of net sales. Market-to-Book is the market value of equity divided by the book value of equity. Stdev_Ret and Stdev_Roa are standard deviations of stock returns and standard deviations of return on assets for the past five years, respectively. CEO_Chair is a dummy, equal to one if CEO is the chair of the board. Board_Size equals the number of directors sitting in the board. CEO_Ownership is the number of shares held by a CEO divided by the total number of shares outstanding. Dir_Ownership is the number of shares owned by insider directors divided by the total number of shares outstanding. Lareg_Ownership is the number of shares held by shareholders whose holding is greater than $5 \%$ of the firm's shares divided by the total number of shares outstanding. Non_IndDir is a dummy, which equals one if firms have not voluntarily appointed independent directors in the board and zero otherwise. RC_Setup is a dummy, equal to one if compensation committee is established in that year. $R C_{-}$EarlyAdopter is a dummy, equal to one if the compensation committee is established prior to 1 December 2011 for firms with share capital less than NT \$10 billion, and if the compensation committee is set up prior to 1 September 2011 for firms with share capital greater than NT \$10 billion. Year and Industry dummies are dummy variables controlling for year and industry effects. 


\section{Conclusions}

The purpose of this paper is to investigate the role of remuneration committee in determining CEO annual pay. Four research issues are addressed in this paper: first, whether CEO annual pay is higher for firms that do not appoint independent directors. Second, if the answer to the first question is "Yes", we examine whether the setting up of RCs can mitigate this issue. Third, we test if the establishment of RCs can align CEO pay and firm performance to any great extent. The forth question is whether the establishing of RCs can enhance the pay-performance association to a greater degree for firms that do not appoint independent directors. Finally, we investigate if early adopters of RCs demonstrate a tighter pay-performance relation.

The findings are summarized as follows: First, we find that CEOs of firms that do not appoint independent directors do have a greater level of annual pay than that of firms that have appointed independent directors, after controlling for the effect of CEO pay-determinant variables. Second, we find that CEO pay in the case of early adopters of RCs is more closely related to firm performance. Third, we find that the setting up of RCs may decrease CEO pay and enhance the pay-performance association, in particular for firms that have not appointed independent directors; however, the effect is not found to be statistically significant.

The findings of this study provide several interesting and important insights for the regulator. First, the independence of board does play an important role in determining the levels of CEO pay. The corporate governance structure for firms having not appointed independent directors reveals some weakness in terms of the efficiency of CEO pay contract and the set up of RC may provide an effective supplementary monitoring tool. Second, the effectiveness of RC as a disciplinary mechanism of CEO pay policy could be different for different firms depending on the firm motives to improve their pay policy, which is evident by the closer pay-performance relation for the RC early adopters.

\section{Acknowledgements}

We gratefully acknowledge the comments and suggestions of two anonymous referees. Chii-Shyan Kuo acknowledges the financial support from National Science Council of Taiwan (Project No. NSC 101-2410-H-006-043).

\section{Conflicts of Interest}

The authors declare no conflict of interest.

\section{References}

1. Jensen, M.; Murphy, K.J. Performance pay and top-management incentives. J. Pol. Econ. 1990, 98, 225-264.

2. Hall, B.J.; Liebman, J.B. Are CEOs really paid like bureaucrats? Quarterly Journal of Economics 1998, 113, 651-692.

3. Yeh, Y.H.; Lee, T.S.; Woidtke, T. Family control and corporate governance: Evidence from Taiwan. Int. Rev. Financ. 2001, 2, 21-48. 
4. Yeh, Y.H.; Woidtke, T. Commitment or Entrenchment? Controlling Shareholders and Board Composition. J. Bank. Financ. 2005, 29, 1857-1885.

5. Liu, W.-C. Are you ready for remuneration committee? Taiwan Corporate Governance Association (TCGA), 2011 (http://www.cga.org.tw).

6. Fama, E.; Jensen, M.C. Separation of ownership and control. J. Law Econ. 1983, 26, 301-325.

7. Jensen, M.C. The modern industrial revolution, exit, and the failure of internal control mechanisms. J. Financ. 1993, 48, 831-880.

8. Tosi, H.; Katz, J.P.; Gomez-Mejia, R. Disaggregating the agency contract: The effects of monitoring, incentive alignment, and term in office on agent decision making. Acad. Manag. J. 1997, 40, 584-602.

9. Cadbury, A. Report of the Committee on the Financial Aspects of Corporate Governance; Gee: London, UK, 1992.

10. Greenbury, R. Report on Directors Pay; Gee: London, UK, 1995.

11. Daily, C.M.; Johnson, J.L.; Ellstrand, A.E.; Dalton, D.R. Compensation committee composition as a determinant of CEO compensation. Acad. Manag. J. 1998, 41, 209-220.

12. Linck,J. S.; Netter, J.M.; Yang, T. The determinants of board structure. J. Financ. Econ. 2008, 87, 308-328.

13. Rosenstein, S.; Wyatt, J.G. Outside directors, board independence and shareholder wealth. J. Financ. Econ. 1990, 26, 175-191.

14. Conyon, M.J.; Peck, S.I. Board control, remuneration committees, and top management compensation. Acad. Manag. J. 1998, 41, 146-157.

15. Newman, H.A.; Mozes, H.A. Does the composition of the compensation committee influence CEO compensation practices? Financ. Manag. 1999, 28, 41-53.

16. Mishra, C.S.; Nielsen, J.F. Board independence and compensation policies in large bank holding companies. Financial Management 2000, 28, 51-70.

17. Vafeas, N.; Waegelein, J.F.; Papamichael, M. The response of commercial banks to compensation reform. Rev. Quant. Finan. Acc. 2003, 20, 335-354.

18. Boone, A.L.; Field, L.C.; Karpoff, J.M.; Raheja, C.G. The determinants of corporate board size and composition: An empirical analysis. J. Financ. Econ. 2007, 85, 66-101.

19. Finkelstein, S.; Hambrick, D. Strategic Leadership: Top Executive and their Effects on Organizations; West Publishing Company: Eagan, MN, USA, 1996.

20. Cohen, L.; Frazzini, A.; Malloy, C. Hiring cheerleaders: Board appointments of "independent" directors. Working paper, Harvard Business School: Cambridge, MA, USA, 2010.

21. Anderson, R.C.; Bizjak, J.M. An empirical examination of the role of the CEO and the compensation committee in structuring executive pay. J. Bank. Financ. 2003, 27, 1323-1348.

22. Perry, T.; Zenner, M. Pay for performance? Government regulation and the structure of compensation contracts. J. Financ. Econ. 2001, 62, 453-488.

23. O'Reilly, C.; Main, B.; Crystal, G. CEO compensation as tournament and social comparison. Admin. Sci. Q. 1988, 33, 257-274.

24. Ezzamel, M.; Watson, R. Executive Remuneration and Corporate Performance. In Corporate Governance: Responsibilities, Risks and Remuneration; Keasey, K., Wright, M., Eds., Wiley: Chichester, UK, 1997; pp. 61-92. 
25. Main, B.G.M.; Johnson, J. Remuneration committees and corporate governance. Accounting and Business Research. 1993, 23, 351-362.

26. Young, S. The increasing use of non-executive directors: Its impact on UK board structure and governance arrangements, J. Bus. Financ. Acc. 2000, 27, 1311-1348.

27. Laux, C.; Laux, V. Board committees, CEO compensation, and earnings management. Acc. Rev. 2009, 84, 869-891.

28. Sun, J.; Cahan, S.F.; Emanuel, D. Compensation committee governance quality, chief executive officer stock option grants, and future firm performance. J. Bank. Financ. 2009, 33, 1507-1519.

29. Mace, M. Directors: Myth and Reality. Harvard Business School Press: Boston, MA, USA, 1986.

30. Jiraporn, P.; Singh, M.; Lee, C.I. Ineffective corporate governance: Director busyness and board committee memberships. J. Bank. Financ. 2009, 33, 819-828.

31. Gilson, S., Bankruptcy, boards, banks, and blockholders, J. Financ. Econ. 1990, 27, 355-387.

32. Kaplan, S. N.; Reishus, D. Outside directorships and corporate performance, J. Financ. Econ. 1990, 27, 389-410.

33. Ryan, H.E., Jr. ; Wiggins, R., III Who is in whose pocket? Director compensation, board independence, and barriers to effective monitoring. J. Financ. Econ. 2004, 73, 497-524.

34. Core, J.E.; Holthausen, R.W.; Larcker, D.F. Corporate governance, chief executive officer compensation and firm performance. J. Financ. Econ. 1999, 51, 371-406.

35. Yermack, D. Companies' modest claims about the value of CEO stock options awards. Rev. Quant. Financ. Acc. 1998, 10, 207-226.

36. Baker, T.A. Option reporting and the political costs of CEO pay. J. Acc. Auditing Financ. 1999, $14,125-145$.

37. Elloumi, F.; Gueyie, J. CEO compensation, IOS and the role of corporate governance. Corp. Gov. 2001, 1, 23-33.

38. Smith, C.W.; Watts, R.L. The investment opportunity set and corporate financing dividend and compensation policies. J. Financ. Econ. 1992, 32, 263-292.

39. Lambert, R.; Larcker, D.; Weigelt, K. The structure of organizational incentives. Adm. Sci. $Q$. 1993, 38, 438-461.

40. Amacom. Executive Compensation Service: Top Management Report. American Management Association, New York, USA, 1975.

41. Newey, W.K.; West, K.D. A simple, positive semi-definite, heteroskedasticity and autocorrelation consistent covariance matrix. Econometrica 1987, 55, 703-708.

(C) 2014 by the authors; licensee MDPI, Basel, Switzerland. This article is an open access article distributed under the terms and conditions of the Creative Commons Attribution license (http://creativecommons.org/licenses/by/3.0/). 